Intimate Enemies 



\section{AARON BOBROW-STRAIN}

\section{Intimate Enemies}

Landowners, Power, and Violence in Chiapas

Duke University Press Durham \&́London 2007 
(C) 2007 Duke University Press

All rights reserved

Printed in the United States of America

on acid-free paper $\infty$

Designed by C. H. Westmoreland

Typeset in Carter \& Cone Galliard with Quadraat Sans

display by Keystone Typesetting, Inc.

Library of Congress Cataloging-in-Publication Data

appear on the last printed page

of this book. 